\title{
The Islamic Principle of Kafala as Applied to Migrant Workers: Traditional Continuity and Reform
}

\author{
Ray Jureidini and Said Fares Hassan
}

\section{Introduction}

The paper is an attempt to identify the continuities and discontinuities between the religious Islamic notion and practice of kafala (kafāla) and its contemporary application - with specific reference to the Gulf States where it has been most prominently legislated and practiced. While much research has been undertaken, mostly critical of the kafala as a system of oppression and exploitation of migrant labour in the GCC, there seems to be a consensus that there is no relationship at all between the traditional Islamic concept of kafala and its current application. In other words, it is argued that there is no evidence of a "genealogy" that links the Islamic jurisprudence of kafala to its contemporary forms (Franz 2011, 98).

In a recent paper on the origins of the kafala related to migrant labour in the GCC, the historian, AlShehabi (2019), provides documentary evidence showing how the British colonial rulers, first in Bahrain and later other GCC states from the 1920s, introduced what was for them a system of sponsorship and surety, but which was perfectly compatible with and adaptable to the principles of kafala in Islamic law and custom. It was, he argues, a "cheap" means of controlling foreigners and having local citizens take responsibility for them. Thus, there was no conscious decision on the part of the Muslim rulers of the region to apply the traditional form of kafala under new circumstances in the GCC that required massive numbers of foreign companies and workers. Rather, in this situation, the conflation of colonial rule and Islamic custom came together serendipitously. Notwithstanding this historical backdrop, we think it is worthwhile to attend to some of the nuances of the "old" kafala and the "new" kafala in order to see more precisely: 1) how it came about; 2) what are the similarities (apart from the name); 3) why the old kafala was modified into its present-day arrangements.

It is argued that the modern Islamic state, through the right of the leader (waliy al-amr and his siyāsa shar'iyya), has the right, the power and authority 
to modify rules and regulations from traditional practices in accordance with the public interest (mașlaha). This is a political dimension that has not been alluded to in previous accounts of the kafala as applied to contemporary management of migration workers in the Middle East. There is a considerable degree of criticism of the contemporary use of kafala. One author, for example, considers contemporary practice of kafala as an "insult to Islam." (Kakande $2015,15)$. Others have equated kafala with "modern day slavery" (Chidiac 2014). It may be argued, however, that the contemporary problems of kafala are primarily because of the abuse of the principles rather than the principles themselves. In this sense, is there a continuity of a normative set of social arrangements, but that the exploitative potential has overtaken the ethical guidelines of trust, care, responsibility and obligations in relation to the presence and employment of foreigners? From the law and religious dicta through fatwas, we provide evidence of traditional ethical continuity, some traditional elements in the codified law, but non-compliance in contemporary practicea perennial problem.

\section{Similarities and Dissimilarities}

The term "kafāla" has a wide semantic scope in Arabic. Its root, kāf - fā" - lām (كل) ), means to feed, support, vouch for or warrant; hence "kafala" refers to bail, guaranty, security or sponsorship (Wehr 1994, 976). According to Lane's nineteenth century Arabic dictionary, kafala meant "responsibility; answerableness; amenability; or suretyship; the conjoining of responsibility to another" (Lane 1872, 3001). Likewise, the kafil is "one who is responsible, answerable, amendable, or a sponsor or surety" (ibid.). In the Islamic tradition, Kafala is a significant concept that has its social, moral and business dimensions. In Islamic family law "kafala" refers to a formal agreement to provide temporary support for an orphaned child until adulthood. Such support does not confer inheritance rights and is best understood as a form of legal guardianship rather than adoption. (Franz 2014, 97)

Businesswise, Muslim jurists extend the meaning of kafala to a business contract where someone formally guarantees somebody else in terms of delivering goods or carrying financial responsibilities (e.g., Ibn Rushd 1999, vol.1, 636-ff; Ibn 'Ābdīn 2003, vol.7, 553-ff). More generally, kafala was intended to provide a framework of social solidarity based on trust and cooperation among people in various realms of their interactions. 
Kafala thus originally refers to a contract where a guarantor conjoins a guaranteed person (makfül) and assumes liability for that person in various specified terms. Kafala is meant to provide an assurance of the fulfillment of an obligation of the guaranteed person. This can be to guarantee the payment of the guaranteed person's financial liability (kafala bi-al-māl) (as in a surety guaranteeing the repayment of a debt). It could also be to guarantee the presence of a certain person at a specified time and place (kafala bi-al-nafs) or the appearance of a certain person, as in the case of a lawsuit (kafala bi-al-wajh) (as in guaranteeing bail money). It could be a guarantee for the delivery of goods (kafala bi-al-taslim) or a guarantee for the purchase of goods sold (kafala bi-al-darak). In short, the guarantor assumes responsibility for a certain liability due by the guaranteed that will include the kafil as a representative of the guaranteed (makfül) in front of the state and other government institutions and take responsibly for any breach of the law perpetrated by the guaranteed (see Bālī 2013, vol.1, 97off; Ibn 'Ābdīn 2003, vol. 7, Chapter on Kafala).

Thus, kafala contracts were used to protect the weak and vulnerable by instituting the patronage of a prominent local who provided whatever protection was required - a form of community responsibility for financial, legal or political representation (Franz 2014, 99). These forms or applications of kafala can still function in contemporary times. However, while the Majella (Ottoman codified Shari'a law) refers to kafala contracts of the various types mentioned above, there is no mention of kafala in the enactment or employment of labour (ibid.). Similarly, there is no mention of kafala contracts in analyses of Ottoman slavery arrangements (ibid.), although similar practices with nonMuslim foreign labour were evident in the port of Istanbul from the late sixteenth century (see Kanchana 2018, 8).

The earliest account of kafala in relation to labour in the Arabian Gulf seems to have been loose arrangements from the turn of the twentieth century to the 1940s (Longva 1997). Pearl divers, for example, were bound to a kafil who owned the dhow boats that were used. This has been identified more as a "cultural legacy" (Hamza 2015: 94; Gardener 2010). As noted for Kuwait, there was no formal legal reference to kafala until the Aliens Residence Law in 1975, despite the requirements from the 1950s and 196os that foreign businesses required a local Kuwaiti partner with 51 percent ownership and that migrants should be "vouched for by a respected citizen of Kuwait" (Longva 1997: 78).

As such, the similarity between the classical Islamic usage of kafala and the new form as applied to the management of foreign workers has been seen as a merely linguistic one that lends it a "veneer of legitimacy," i.e. the presence of a kafil as guarantor (now sponsor) who would guarantee the legal residency of 
the foreigner who will abide by the rules of a contract and the laws of the country. As Franz observes,

If the current use of the kafala system for migrant labour did descend from these earlier forms, it diverged dramatically in the context of nation states and neoliberal market forces and transformed into a system whereby non-nationals are bound to nationals for the purposes of work or business. (Franz 2014, 100)

The most highly critiqued issues of the contemporary kafala have indeed centered around the power, control and exploitation of the kafil over foreign employees as well as business establishments. The criticisms have primarily been based on international human and labour rights law and conventions (International Labour Organization 2013a; Kapiszewski 2001).

On the other hand, investigating the technical usage and application of the classical Islamic kafala system, it is clear that an essential element of the classical system is that kafala is considered a contract without benefits on the part of the guarantor. That is, the service of the guarantor ( $k a f i l)$ is meant to be free of charge.

Nothing in the Ottoman or figh contexts referred to the use of such contracts for the purpose of rewarding the guarantor. Such a situation would in fact have constituted a legal breach since any payments made to the guarantor for providing kafala would have constituted riba (usury), forbidden in Islam. (Foster 2001, 143)

It is in this sense that the new kafala may seem to violate a key traditional Islamic condition and may be seen more as a business-oriented system rather than one of trust and protection. A kafil sponsors a worker and represents him/ her on behalf of the state on the condition that this specific worker will sign a contract to work for him or for others in return for certain benefits. It is not a pure kafala system. It is a kafala-cum-ijära (sponsorship-cum-hiring) system, and in this sense the kafala-makfül relationship has been reversed where the makfül guarantees the fulfillment of a labour contract with the kafil who pays the makfül for his/her labour, presumably making a profit from the labour. This new relationship is no longer kafala. The question remains, however, to what extent is this form of contract Islamically justified and reasoned?

1 Although it is not pursued here, it should be noted that, while foreign companies require 51 per cent ownership by a national (individual or company), not all kafils/sponsors of migrant 
However, let us look more closely at the distinction between the principle and the practice. Although the original idea may have been for GCC citizens to take responsibility for the presence of foreigners, particularly professionals in the energy industries, the system quickly metamorphosed into one where the kafil was not held responsible or accountable. For example, the kafil is the one responsible for the obtaining of a work visa and residency permit. However, if the residency permit was not renewed, the employee becomes an illegal resident liable to arrest, detention and deportation, not the kafil. Thus, the original idea of the kafil taking responsibility for the makfül does not resonate in the new form. As Franz notes, the kafala as adapted to migrant labour, "violates both the letter and spirit of the legal institution," where "something once associated with social protection has become more restrictive and punitive" (Franz 2014, 101).

As an example, it was the 1959 Kuwait Alien Residence Law and its several amendments $(1963,1965,1968$, and 1975) that made all migrant workers virtually dependent on their Kuwaiti employers for their entry visas, work, and residence. However, neither the content of the kafala nor the relationship between the kafil and the migrant worker were clearly explained in the law (Alajmi 2007). Longva suggested it may have been because, "The [kafala $]$ practice was well-anchored in Kuwaiti tradition and was, therefore, widely understood and taken for granted by the native population" (Longva 1997, 79). This suggests that the origins of the modern kafala was a more cultural, customary heritage rather than one based upon Islamic jurisprudence.

Current practice of the kafala system has been critiqued for its exploitation of migrant workers, to the extent of describing it as a slave system (Rodriguez 2014). It puts severe restrictions on labour mobility, and has prevented the development of a local labour market. Kafils may withhold workers' payments while demanding longer hours and preventing access to legal rights by withholding workers' passports, contract substitution and the like (Jureidini 2014). Kafils may also lease their kafala against payments. Workers may be forced to pay recruitment charges to the recruitment agency, thus burdening the workers with more expenses, feeding a system of bribery and corruption and binding them into a form of labour indebtedness and forced labour (Jureidini 2017a). There are many other forms of exploitation and malpractices of kafala (and where the kafil profits) that are against the law and indeed frowned upon from an Islamic perspective.

workers in the Gulf States are nationals. They can also be non-nationals who have residency (iqāma). This means that a kafil/sponsor can also be a non-Muslim. Further empirical research into the topic should take this into account. 
In an answer to frequent questions on the Islamic legal framework of recruiting foreign workers through kafala in Saudi Arabia, the Permanent Committee of Scientific Research and Fatwas published a long research paper to provide legal reasoning for the legality of kafala and the parameters that should be considered in its application. The committee started its presentation by confirming that recruiting foreign workers is part of the state policy to care for the interests of its people. Consequently, the administration of labour recruitment is subject to the approval of the King, as the head of the state and the one in charge of the affairs of Muslims, i.e. the waliy al-amr (al-Lajna alDāima 1994, 39-6o).

According to Islamic law, the waliy al-amr can issue laws to regulate people's lives (Taj, 1995, 33), including businesses in a way that protects the rights of contractors and the needs of the society, provided that these laws do not contradict a Qur'anic injunction or a Prophetic instruction. Given his powers, the waliy al-amr may exercise ijtihäd and enact laws that command people to follow a certain set of regulations (and not others, even if those others are religiously permissible in themselves). People should abide by these regulations, or otherwise they will be of "the transgressors" (al-Lajna al-Dāima, 41). These regulations may provide rules of business such as work times, work places, work permits, job descriptions, etc. If such regulations exist, then people must follow them, otherwise they may be subject to certain penalties. This understanding of the rule of the waliy al-amr is formulated in the legal maxim, "tașarruf al-imām 'alā al-raciyya manūt bi-al-mașlaha," i.e. the imam's power over his people is based on his effort to maintain their interests (al-Suyūțī, 1983).

Based on these arguments, the kafala/sponsorship laws are considered part of this siyassa. It is argued that the regulation of the process of kafala or hiring foreign workers is a task of the waliy al-amr or his representative. The regulation defines who should be recruited, conditions of their recruitment, rights and duties of both kafils (sponsors / employers) and the makfüls (sponsored / employees). The main function of this regulation is to guarantee the interest of the work itself, the maintenance of security, the prevention of chaos and tension in the work environment. Once these regulations are set, both sides, employers and employees, should follow the contractual conditions and commit themselves to its conditions. In so doing, they follow the Quranic injunction, "O, you who believe, commit yourselves to your contracts"; and to the Prophetic directive, "Muslims must commit to their conditions, and whoever neglects them, he is from the transgressors." If they do not abide by them, then the waliy al-amr may discipline them in the way he thinks appropriate (al-Lajna alDāima, 41). 
It has been argued that the kafala contract controls the movements of workers and subjects them to a set of draconian practices (e.g. keeping their passports, delaying their payments, forcing them to work more hours, etc.) that are against international labour law. To what extent, however, are these practices Islamic?

To discuss the laws of kafala, one needs to turn to the section on ijära in Islamic law texts. The definition of kafala shows clearly the relationship between the new form of kafala and ijära. Kafala refers to the permission given by the state to a certain individual/company to sponsor/hire non-natives to work for them through a contract to be signed and approved by both parties. This contract should state at least the names of the employer and the employee, the nature of the work, and the salary agreed upon. This contract is very similar to an ijära contract in Islamic law. Jurists define ijära as a contract to provide a lawful specific service to be performed in a specific span of time in a specific place for a specific wage/cost/benefit (al-Nahhām, 2011) —in short, "the trade of a particular service for a specific return" (Bālī 2013, 589).

Discussions of the kafala system in legal debates follow the same line of arguments in Islamic contracts in general and contracts of ijära in particular in the sense that contract conditions are binding, business ethics have to be observed and elements of gharar (an element of contracts or exchange, usually in finance, associated with deception, risk and uncertainty — of dubious legitimacy) have to be eliminated. Reviewing ijära sections in Islamic legal texts reveals that the ijära contract requires precision, clarity, eligibility and approval. Missing one of these elements may invalidate the whole contract. Furthermore, the kafala system is more or less identical with the legal discussion of the ajīr khāṣ (private employee) (al-Nahhām 2011).

Generally, contracts are binding and sacred in Islamic law, provided they do not violate the principles of Sharita and the public interest. The contractual relationship is not seen from within the exclusive realm of the contractors but also on the consideration that Allah oversees this relationship, not only as a guarantee of honoring the contract and maintaining contractual justice, but also as the Actual Disposer of Affairs (Shimizu 1989). A contract in Islam thus has a religious component within it, even if not stated explicitly in the contract. This has to do with two main points. First, contracts are based on the usufruct principle, namely, everything belongs to and is owned by Allah and man is only a trustee with usufruct rights (Doi 1984, 355). This means that the contracting parties should assume the presence of Allah as the Actual Contractor and that the subject matter of a contract has to be legally permissible. Second is the 
element of moral commitment that starts with the elements of intention and motive at the moment of undertaking the contract. Ibn al-Qayyim argues, "the motive behind the contract is an essential consideration and affects its validity" (Coulson 1984, 45). In other words, the individual conscience plays a significant role in the genuine accord of wills and mutual agreement among business partners. "The attitude of [Muslim] jurists endeavors to understand the total context or the real situation by examining the real intention of the individual. That is to say, it seeks for substance, and is not overly concerned with formalism..." (Shimizu 1989, 16).

In addition to the morality of the motive, moral commitment can also be observed through the principle of taqwa - literally, the fear of God and piety. The Qur'an says, "Men, We have created you from a male and a female and divided you into nations and tribes that you might get to know one another. The noblest of you in Allah's sight is atqākum (the one who fears Him most), Allah is wise and all-knowing" (Quran 49:13). In Islam, taqwa $\bar{a}$ is the standard for the judgment of human actions. In action, taqwā means faithfulness or a desire to love all things universally in a social sense. This understanding is the more significant of the two connotations in considering the function of community, because the most precious relationships of human beings in a community are those founded on the basis of love or brotherhood. These relationships create a voluntary regard for others more than one's self, leading to unity and stability of a community. Taqwa always involves a sense of love and sympathy for others (Shimizu 1989, 43-44). In this sense, it creates a subconscious respect for compliance to certain principles that may be beyond the reach of formal enforcement.

In addition to the sacred, binding and moral nature of the contract, Islamic law stipulates that the contractors should not have conditions that may result in deceiving one of the contract parties, a kind of moral hazard. In technical terms, a contract should not have gharar, such as a practice or condition that may cause a profit for one party but a corresponding loss for another (Coulson $1984,44)$. Thus, one of the reasons why gharar should be eliminated is that its absence is a precondition for confirming the equilibrium in a contract. Contracts are never legally bound until the real equilibrium (among the interests of contractors, the wellbeing of the community and the Will of the Divine) is ascertained. Thus, the kafala system can be Islamically reasoned and justified if it is framed in line with rules of contracts as established in Islamic law. If there is a breach of these rules, jurists will argue against these as malpractices.

As an example, in certain instances, employers have used the system to hire workers but exploit them by asking them to work for another employer, provided that the worker pays him either a percentage of his earnings or a set 
amount of money each month. In other instances, the employer hires workers with a certain wage, but once these workers arrive in the country, arrangements are made for them to work for another company with a higher wage, the kafil taking the difference into his own pocket. In both cases, muftis from the Saudi General Committee for Ift $\vec{a}$ and Research made the following comments: First, this form of contract contradicts the laws of the land as enacted by the waliy al-amr to preserve rights, to maintain security, and to prevent problems. Second, it includes earning money in return for the kafala that is, if not a harām, at least a doubtful practice that Muslims are supposed to stay away from. Third, there is a form of gharar and ambiguity in the contract as sometimes the exact salary is unknown, the money for the sponsorship is unknown, and the employer will pay little money (visa, transportation, etc.) in return for a large sum of money to be paid in return (al-Lajna al-Dāima 1994, 56 ). Other fatwas also stressed the unlawfulness of the breach of contract in the kafala system, especially the case when a sponsor would ask his employee to work on his own and give him money in return for his sponsorship (al-'Uthaymīn 1979, 214-5; al-Dawīsh, 377-8).

The argument of the illegality of this transaction is intriguing. Jurists argue that the kafala contract, if not involving direct work arrangement between the two parties, becomes a contract of irfāq and tabarrau, that is, charity, goodness and compassion. Because of this, the kafil should not ask for money. His services should be provided for free. If there has to be some money to be paid, then it can only be the costs the sponsor incurred to secure the needs of his "brother" (fatwa.islamweb.net, fatwa no. 137333). But even this is a problem because the labour law in Saudi Arabia forbids workers to be charged for recruitment costs and fees. ${ }^{2}$ The visas obtained on a sponsorship principle are not commodities that one may trade in. They are just permits from the government to bring labourers to work for someone (fatwa.islamweb.net, fatwa no. 101777). Another reason is the element of deceit and cheating to the state, as the sponsor's action defies the purpose of the kafala system (islamqa.com, fatwa no. 101220).

A direct question from a kafil regarding the taking of money from the makfül was put to the Saudi General Committee for Ift $\bar{a}^{\prime}$ and Research. It was in

2 "An employer shall incur the fees pertaining to recruitment of non-Saudi workers, the fees of the residence permit (Iqāmah) and work permit together with their renewal and the fines resulting from their delay, as well as the fees pertaining to change of profession, exit, re-entry visas and return tickets to the worker's home country at the end of the relation between the two parties." (Article 40, Saudi Labour Law, 2005); similarly, in the UAE (Article 18, UAE Labour Law No. 8, 1980) and Qatar (Article 33, Qatar Labour Law No. 14, 2004). 
relation to employees who wanted to remain in the state even though he could no longer employ them:

I am the sponsor of a number of Afghani workers and have no work for them at the present time. They, thus, engage in other work in the country and live in my house without paying rent. They keep the money they gain from work for themselves, whether it is a small or large amount. However, they pay me three thousand riyals for renewing their two-year residence permit and referring to the concerned authorities. I have asked them to return to their country, but they have entreated me not to withhold their Rizq (sustenance). Am I sinful for this? (Asadov 2015, 46)

The principle concern of the fatwa committee was that the kafil should not receive any money just for extending their visas, for that is the kafil's responsibility. ${ }^{3}$ Other similar inquiries met with fatwas strictly prohibiting the taking of money from the makfül.

In addition to the fatwas, the practice of sponsors profiting from selling work visas to workers abroad and not providing employment has come to be known as "visa trading" or "free visas" (free of a job, not free of cost). Although widespread in the GCC over many decades (Fargues \& Shah 2017), these practices are not condoned as a part of the kafala but are strictly illegal and perpetrators have been prosecuted, fined and blacklisted (see, for example, Sophia 2015; Qatar News 2014; Gulf Times 2018).

Interestingly, there is some similarity in the principle restrictions governing kafala as a means of fostering an orphan child. ${ }^{4}$ Here, the kafil also must not take money for rearing an orphan, but at the same time, the orphan is not to assume a blood identity with the family, particularly with regard to inheritance. Rules regarding marriage of fostered orphans also suggest the same form of distinction or separation. Kanchana notes that in kafala fostering,

There is no change in the family name and the child does not get inheritance rights. The objective is to protect the original identity (including family relationship and religion) and the inherited property of the child. While kafala care could imply benefits such as access to the wider family

3 Interestingly, Asadov argued that the "highly moralistic approach" of the Saudi scholars issuing the fatwa was not helpful in reconciling the law with the reality; that the fatwa could have acknowledged that money could not be legitimately received for the visa extension, but for rent and thus "serve the interest of both" (Asadov 2015, 47).

4 "Many Muslim-majority countries do not recognize adoption and they instead facilitate a fostering arrangement, called kafala" (Kanchana 2018: 7). 
and the social networks, it also stresses the child's dependence on the adoptive parents' benevolence. (Kanchana 2018, 7)

The separation and dependence are similar to kafala in relation to foreign employees, where rights of citizenship are denied, but for different reasons (Dito 2014). As Lori (2012) notes, kafala has two key structural elements in the Gulf States. First, there is a government centralization where the sponsorship laws are administered through the Ministries of Interior that regulate entry work permits (visas) and residency, "without any outside intervention by the courts or other institutions." Second, citizen sponsorships of foreign individuals or corporations constitute "a built-in enforcement mechanism for temporary residency by holding citizens directly responsible for the residency violations of non-citizens." In this way, the "mechanisms for enforcing temporary residency are widely dispersed while authority over residency decisions remains highly concentrated" (Lori 2012,12). And as Fargues notes, the demographic imbalance has meant that "decades of intense, but temporary, migration have resulted in citizens and non-nationals growing as two separate entities without a new, mixed, population emerging from their co-existence" (Fargues 2011, 280).

These fatwas and similar malpractices of the system show the disparity between the Islamic principles of kafala and exploitative practices and demonstrate the power relationship between the local citizens and foreign workforce. To treat these issues on the state level, many GCC states have been discussing the kafala system and introducing various amendments and reforms to their laws, hoping to create more equilibrium in the relationship between the businessman, the worker and the interests of the state.

One of the recent attempts in reforming the kafala system is in Qatar (see Jureidini 2017, 2014). By way of background, the original 1963 kafala legislation (Law 9, Governing Aliens Entry and Residence in Qatar) was drawn up with skilled professionals in mind, making it clear that foreigners can be granted an entry visa for work provided that they filled a technical expertise that Qatar requires. Second, that foreigners must have Qatari kafils who are able to hire and care for them. Third, that the kafil is required to sign a statement of the good conduct of the makfül and make a commitment to present the employee to the Qatari authorities at the end of the contract and also commit to pay for their repatriation home. Reference to kafala, kafil and makfül were included right up to the 2009 legislation (Law 4, Regulating the Entry and Exit of Expatriates in Qatar and their residence and Sponsorship) with a more explicit requirement of an exit visa to be approved by the employer and which came under much criticism that it violated the right of freedom of movement (see for example: Human Rights Watch 2012; International Labour Organization 2013; Amnesty International 2013, 2016). 
Despite the practices of preventing employees from leaving the country at will, the legislation requiring an exit visa was again mainly aimed at professionals and business people who may be in a position to defraud or leave the country with large debts that would not be repaid, perhaps the result of bitter experience. Article 19 states that the kafil must "be qualified to bear the obligations of the sponsorship as imposed by law and employ the expatriate under its own supervision." Provisions were also made distinguishing between a kafil al-iqāma (the residency sponsor) and kafil al-khurüj (the exit sponsor, in case the residency sponsor was unavailable to sign off, or deceased). In either case, the kafil is responsible for any debts of the makfül and to "present a certificate from the authorized administrations that there is no claims or court decisions against him." Article 20 made clear that the residence or exit kafil would only be responsible for the debts of the expatriate and no more. It states that the kafil (in both of its categories as kafil al-iqäma (sponsor of one's stay/visit to Qatar) and kafil al-khurüj (sponsor of the makfül in case of his departure) should not carry the responsibilities or be charged money more than what the makfül owes. For example, if the makfül has to pay 500 in debt, the kafil is responsible for these 500 only, not more. In addition, there should not be any further conditions than those already due on the makfül. For example, if the makfül has to pay his debt in installments, it remains that way and the kafil cannot be asked to pay it in a lump sum. The kafil's responsibility for the debts of the foreigner was thus quite clear and consistent with the traditional kafala requirement. Of course in practice it was most unlikely that a kafil would allow a situation where he would be required to pay the debts of a foreign makfül. Indeed, it was precisely through the mechanism of the requirement of permission for an exit visa that allowed a sponsor to legally detain a foreigner when there was any form of dispute between them.

The most recent reform was Qatari law no. 21 in 2015 (Regulating the Entry, Exit of Expatriates and their Residence), which came into force in December 2016. ${ }^{5}$ Reading this law closely, one can notice the following: First, there was a change in the level of language used. The term "kafala" and its derivatives have been eliminated from the whole document. They were replaced by the term wăfid (newcomer; in Arabic tradition, the "wāfid" has to be dealt with generously and honorably), rather than makfül, which if not a positive term, is at least a neutral one that does not carry negative implications, other than that the

5 This is the latest amendment to the law regulating the entry, exit and residence of expatriates in Qatar, administered by the Ministry of Interior. The first was in 1963 (Governing Aliens Entry and Residence in Qatar) and amended in 1973, 1984, 1998, 2002, 2004 and 2009 (see Malaeb 2015). 
person is not a citizen of the country. Also the kafil (sponsor) is now called almusatqdim (the one who summons the newcomer; sometimes translated as the recruiter, but this gets confused with recruitment agents so is less used). The "exit visa" was replaced with a "travel notice," but still requiring employer approval and the foreign employee can change employers at the completion of their contract. The musatqdim can make objections, but the onus is on them to provide valid reasons before grievance tribunals that have been established. Second, as before, the law is not only about low-skilled workers but it covers all non-nationals coming to Qatar, a matter that makes workers equal to other categories of non-nationals at least on the theoretical level. Third, there is no reference to any Islamic terms per se, a matter which recalls the role of the waliy al-amr in determining certain regulations as binding, even if these regulations are not referred to in the Qur'an and Sunnah. Fourth, the law establishes criteria for deportation, reconciliation and penalties, in an attempt to present a balanced position. To what extent the law is balanced or provides protection to the "newcomer" is a debatable matter, but the reform law and other commitments have satisfied the International Labour Organization that in November 2017 withdrew its complaint threatening a commission of inquiry.

More importantly for this discussion, the Qatar authorities have made clear that the kafala system has now been abolished in favour of a system that relies solely on the contractual relationship between the employer and employee (see International Labour Office 2017). Although it may be argued that a number of elements of control (and exploitation) over foreign workers have not been abolished, the conceptualization and emphasis on contractual relations is more explicitly ijära, but articulated in secular terms.

\section{$4 \quad$ Conclusion}

The Islamic tradition of kafala, be it a kafala of an orphan, of a stranger, of a needy person, or for a business transaction, seems to be categorically different from the new forms of contemporary practices of kafala in the GCC working environment. Still, however, there are certain elements of continuity between the two systems of kafala, in the sense of the continuity of the guarantorship of the kafil to the makfül. Traditionally, kafala means to transfer the duties of the makfül to the kafil. Thus, if the makfül has to pay money or to deliver a certain commodity, the kafil stands in for the makfül and becomes responsible for the delivery of the money, the commodity or the person. If the makfül does not deliver, the kafil carries the responsibility. The same concept of guarantorship 
remains in the new kafala form, though in a different mode. The kafil becomes responsible for the makfül in terms of facilitating and regulating his/her life in the country. This kafil-makfül relationship is not a business-based contract (where the kafil offers kafala in return for certain benefits). It is, on the contrary, a "contract" which is based on voluntary cooperation and social solidarity, where no benefit should be gained by the kafil. This principle has a great impact on the Islamic legal discussion of contemporary forms of kafala. Many fatwas, as those presented in this paper, show clearly that any request or expectation of compensation is not Islamically permissible.

This paper suggests that the new forms of kafala, if to be examined from an Islamic perspective, is perhaps better discussed not as a kafala per se, but as a kafala-cum-ijära system. That is, a contract that combines these two systems of transactions and which is now articulated in a secular manner, as in the new Qatari legislation. Although this suggestion requires more discussion from the perspective of Islamic law, it is sufficient given the scope of this paper to argue that the kafala system is a new form of ijära contract that attempts to maintain a customary tradition in the modern world of labour recruitment. To support this understanding, one can note that recent collections of fatwas always discuss questions on kafala under the chapters of ijära (al-'Uthaymīn, 1979; alDawīsh, nd).

Islamic law provides a theoretical framework that seeks to maintain the rights of all contracting parties in a way that keeps the balance among them, not only as work-partners, but also as human beings with moral commitments towards each other and toward God. Contracts may be the governing criteria in formal business discussions in the courtroom, in case of disputes, but intention and taqwā (i.e. real motives and conscience) are the ones to be accounted for before God.

In addition to the religious legal dimension in thinking about modern forms of kafala, the role of the state should be also underlined in this context. The state can interfere to regulate economic businesses in a way that should protect the rights of contractors and the needs of the society. Ibn Taymiyyah argues that "Indeed waliy al-amr (those in charge of the affairs of Muslimsgovernors or their appointed representatives) has the right to force certain workers in certain professions to meet people's needs ... he would set for them the cost of their work, equivalent to a similar job..." (al-Salūs 2001, 64ff).

To what extent this religious-moral-legal foundation is practiced on the ground offers a different question. Exploitation, fraud and harm observed in the practice of modern forms of kafala go against the philosophy of Islamic contracts. It is therefore perhaps incumbent on critics of the contemporary application of kafala to invoke and address the nuances of those Islamic ethical 
principles that should still have resonance within contemporary economic arrangements in Muslim countries such as the Gulf States.

\section{Bibliography}

Alajmi, Abdullah Mohammad. 2007. In the House, Around the House: An Ethnography of Hadar Hadrami Migration to Kuwait. PhD Thesis. London School of Economics and Political Science.

AlShehabi, Omar Hesham. 2019. "Policing Labour in Empire: the modern origins of the Kafala sponsorship system in the Gulf Arab States." British Journal of Middle East Studies, DOI: 10.1080/13530194.2019.1580183.

Amnesty International. November 18, 2013. The Dark Side of Migration: Spotlight on Qatar's Construction Sector Ahead of the World Cup. London: Amnesty International.

Amnesty International. 2016. The Ugly Side of a Beautiful Game. London: Amnesty International.

Asadov, Ayaz. 2015. "Fatwa Making in the Context of Abnormal Justice: The Case of Migrant Workers in Saudi Arabia." In Proceedings, Social Justice and Poverty in Muslim World, International Ilem Summer School, Konya, Turkey, August 1-9, 2015: 43-54.

Bālī, Waḥīd ibn 'Abd al-Salām. 2013. Qawānīn al-Sharīa al-Islāmiyya al-latī Taḥkum bihā al-Dawla al-'Uthmāniyya. Shubra, Egypt: Dār al-Taqwā.

Chidiac, Omaya. 2014. Migrant Construction and Domestic Workers in the Arab Gulf States: Modern-Day Slaves? Master of Laws Thesis, Graduate Program in Law. York University Toronto, Ontario.

Coulson, Noel. 1984. Commercial Law in the Gulf States. London: Graham \& Trotman.

al-Dawīsh, Aḥmad ibn 'Abd al-Razzāq. Fatāwā al-Lajna al-Dāima li-al-Buhūth alIlmiyya wa-al-Iftä'. Vol.14. Riyadh: Dār al-Mu’ayyid.

Dito, Mohammed. 2014. "Kafala: Foundations of Migrant Exclusion in GCC Labour Markets." In Transit States: Labour Migration and Citizenship in the Gulf, edited by Abdulhadi Khalaf, Omar AlShebabi, Adam Hanieh. London: Pluto Press.

Doi, Abdulrahman. 1984. Shariah: the Islamic Law. London: Ta Ha Publishers.

Fargues, Philippe. 2011. "Immigration Without Inclusion: Non-Nationals in NationBuilding in the Gulf States." Asian and Pacific Migration Journal 2o(3-4): 273-289.

Fargue, Philippe \& Nasrah M. Shah, eds. 2017. Skillful Survivals: Irregular Migration to the Gulf. Gulf Research Center. Cambridge: Cambridge University Press.

Foster, Nicholas. 2001. "The Islamic Law of Guarantees." Arab Law Quarterly. 16(2): $133-57$. 
Franz, Elizabeth. 2011. Exporting Subservience: Sri Lankan Women's Migration for Domestic Work in Jordan. PhD diss., Department of Anthropology, London School of Economics.

Gardner, A, Pessoa, S. \& L. Harkness. 2014. Labor Migrants and Access to Justice in Contemporary Qatar. Middle East Center, London School of Economics.

Gardner, Andrew M. 2010. City of Strangers: Gulf Migration and the Indian Community in Bahrain. Ithaca: Cornell University Press.

Gulf Times. 2018. "Three arrested for running fake companies, visa trade." March 20, 2018. <http://www.gulf-times.com/story/585889/Three-arrested-for-running-fakecompanies-visa-tra\#section_178>. Accessed May 27, 2018.

Hamza, Sara. 2015. "Migrant Labor in the Arabian Gulf: A Case Study of Dubai, UAE," Pursuit-a Journal of Undergraduate Research at the University of Tennessee 6(1), Article 10. Available at: <http://trace.tennessee.edu/pursuit/vol6/iss1/10/>. Accessed 27 May, 2018.

Human Rights Watch. 2012. Building a Better World Cup. New York: Human Rights Watch.

Ibn 'Abdīn, Muḥammad Amīn. 2003. Rad al-Muḥtār 'alā al-Durr al-Mukhtār Sharh Tanwīr al-Abṣār, edited by 'Adil 'Abd al-Mawjūd and 'Alī Mu'awwaḍ. Riyadh: Dār 'Ālam al-Kutub.

International Labour Office. 2017. Complaint concerning non-observance by Qatar of the Forced Labour Convention, 1930 (No. 29), and the Labour Inspection Convention, 1947 (No. 81), made by delegates to the 103rd Session (2014) of the International Labour Conference under article 26 of the ILO Constitution. 329th Session of the Governing Body, Geneva, 9-24 March 2017.

International Labour Organization. 2013. Tricked and Trapped: Human Trafficking in the Middle East. Geneva: International Labour Organization.

International Labour Organization. 2013a. The Living and Working Conditions of Migrant Workers in the Gulf Cooperation Council Countries. Geneva: International Labour Organization.

Jureidini, Ray. 2014. Migrant Labour Recruitment to Qatar: Report for Qatar Foundation Migrant Worker Welfare Initiative. Qatar, Doha: Bloomsbury/Qatar Foundation.

Jureidini, Ray. 2017. "Islamic Ethics and Migrant Labor in Qatar." In Labor in an Islamic Setting: Theory and Practice, edited by Toseef Azid and Necmettin Kizllkaya. London: Routledge.

Jureidini, Ray. 2017a. "Transnational Culture of Corruption in Migrant Labor Recruitment." In Migration Research Leaders' Syndicate: Ideas to Inform International Cooperation on Safe, Orderly and Regular Migration. Geneva: Iом.

Kakande, Yasin. 2015. Slave states: the practice of kafala in the Gulf Arab Region. UK: Zero Books. 
Kamrava, Mehran and Zahra Babar. 2012. "Situating Labor Migration in the Persian Gulf." In Migrant Labor in the Persian Gulf, edited by Mehran Kamrava and Zahra Babar. New York: Columbia University Press, 1-20.

Kanchana, Radhika. 2018. "Is it the Kafala Tradition to Blame for the Exploitative Work Conditions in the Arab-Gulf countries?" In South Asian Migration in the Gulf: Causes and Consequences, edited by Mehdi Chowdhury and S. Irudaya Rajan. London: Palgrave Macmillan.

Kapiszewski, Andrzej. 2001. Nationals and expatriates: Population and Labour Dilemmas of the Gulf Cooperation Council States. U K: Garnet Publishing Limited.

al-Lajnah al-Dā’ima li-al-Buhūth al-'Ilmiyya wa-al-Ifā'c. 1994. "Istiqdām al-'Amāla alAjnabiyya wama Yata'allaq bihā min Aḥkām. Majallat al-Buhūth al-Islāmiyya 41. KSA: Al-Ri'āsa al-'Āmma li-al-Buhūth al-'IImiyya wa-al-Iftā', 39-6o.

Longva, Anh Nga. 1997. Walls Built on Sand:Migration, Exclusion and Society in Kuwait, Oxford: Westview Press.

Lori, Noora. 2012. Temporary Workers or Permanent Migrants? The Kafala System and Contestations over Residency in the Arab Gulf States. Paris, Institut Français des Relations Internationales (IFRI), Center for Migrations and Citizenship.

Malaeb, Hanan. 2015. "Kafala System and Human Rights: Time for a Decision." Arab Law Quarterly, Volume 29, Issue 4: 307-342.

al-Nahhām, Șāliḥ. May 2011. "Anwāc al-ijāra." Majallat al-Wa'i al-Islāmi 550.

Qatar News. 2014. "Ministry punish $5^{1}$ companies for illegal visa trade." 5 September 2014. <http://www.qatarliving.com/forum/news/posts/ministry-punish-51-compa nies-illegal-visa-trade $>$. Accessed 27 May, 2018.

Rodriguez, Andres. 2018. "The Kafala System in the GCc." The Gazelle, May 15, 2014. $<$ https://www.thegazelle.org/issue/33/features/kefala-system>.

Shimizu, Hideyuki. 1989. The Philosophy of Islamic Law of Contract, A Comparative Study of Contractual Justice. IMES working paper 15. Japan: IMES, International University of Japan.

Sophia, Mary. 2015. "Saudi Arabia Clamps Down On Visa Trading." Gulf Business. 18 February 2015. <http://gulfbusiness.com/saudi-arabia-clamps-down-on-visatrading/>. Accessed 8 May, 2018.

al-Sālūs, 'Alī Aḥmad. 2002. Mawsū'at al-Qaḍāyā al-Fiqhiyya al-Mu'ạșira wa-al-Iqtiṣād al-Islāmī. Bilbīs, Cairo: Maktabat Dār al-Qurān.

al-Suyūṭi, 'Abd al-Raḥmān ibn Abī Bakr ibn Muhammad. 1983. Al-Ashbāh wa-al-Nazāàir fí al-Furū' al-Fiqhiyya. Beirut: Dar Al-Kotob Al-Ilmiyah.

Tāj, 'Abd al-Raḥmān. 1995. Al-Siyāsa al-Shar'iyya wa-al-Figh al-Islāmi. Al-Azhar Magazine gift, Ramadan issue, 1415 AH. Cairo: al-Azhar Printing House.

al-'Uthaymīn, Muḥammad ibn Șāliḥ. 1979. Fatāwa Nūr 'alā al-Darb. Vol. 9. Riyadh: Mu'assasat al-Shaykh Muhammad ibn Șāliḥ Al-'Uthaymīn al-Khayriyya. 
Vora, Neha. 2013. Impossible Citizens:Dubai’s Indian Diaspora. Durham: Duke University Press.

Wehr, Hans. 1994. A Dictionary of Modern Written Arabic, edited by J. Milton Cowan, 4 th edition, Ithaca: Spoken Languages Services.

OnlineFatwas < http://fatwa.islamweb.net/fatwa/index.php?page=showfatwa\&Option =FatwaId\&Id=137333 $>$. < http://fatwa.islamweb.net/fatwa/index.php?page=showfat wa\&Option=FatwaId\&lang=A\&Id=101777. $<$ https://islamqa.info/ar/101220/ $>$. 